\title{
Simultaneous Estimation of Antipsychotic Drugs (Risperidone and Olanzapine) by RPHPLC
}

\section{Bharat Lal ${ }^{1}$ and Manoj Gadewar ${ }^{2 *}$}

${ }^{1}$ Department of Pharmaceutics, K.R. Mangalam University, Haryana, India

${ }^{2}$ Department of Pharmacology, K.R. Mangalam University, Haryana, India

*Corresponding Author: Manoj Gadewar, Department of Pharmacology,

K.R. Mangalam University, Haryana, India.
Received: June 18, 2021

Published: July 22, 2021

(C) All rights are reserved by Bharat Lal and

Manoj Gadewar.

\section{Abstract}

A rapid, specific RPHPLC technique has been developed for simultaneous resolve of risperidone and olanzapine. Drugs were subjected to stress conditions such as acidic, alkaline and oxidative hydrolysis. Chromatographic separation of these pure drugs was carried with a 50:50 (v:v) mixture of acetonitrile and Potassium Di Hydrogen Phosphate and 40:60 (v:v) mixture of acetonitrile and Potassium Di Hydrogen Phosphate Buffer as mobile stage. The current rate was $1.0 \mathrm{~mL} \mathrm{min-1}$ and the analysis was monitored at 235 nm by UV detection.

Keywords: Risperidone; Olanzapine; RP-HPLC; Acetonitrile; Potassium

\section{Introduction}

Olanzapine and risk phrenic medications for successful therapy for schizophrenia and similar disorders are deemed universally beneficial. In recent years, standard antipsychotic medications in schizophrenia have been substituted by greater effectiveness and lower side effects as part of the therapy of schizophrenia [1,2]. "Atypical" drug combinations are well tolerated and may be useful for schizophrenia treatment [3]. V. Currently, five atypical antipsychotic medications, including clozapine, elanpine, risperidone, ziprasidone and quetiapine, have been licensed for use in the United States (Borison., et al. 1986, Wetzel., et al. 1995, Bymaster., et al. 1996, Janssen., et al. 1988, Daniel., et al. However, no direct way to simultaneously assess risperidone and olanzapine in their combination form was identified in literature surveys. Chemically recognized as 3-(2-(4-(6-fluoro-1,2,2-benzisoxazol-3-yl)-1-piperidinyl) ethyl)-6,7,8,9-tetrahydro-2-methyl-4H-pyrido[1,2-a] is risperi- done and olanzapine 2-methyl-4-pyrimidine 4-one (4-methyl1-piperazinyl) -10H-thieno, respectively [2, 3-b][1,5]benzodiazepine.

The objective of the current research is to establish a quick, special and verified RP-HPLC process in combination pure form for the assessment of risperidone and olanzapine. The technique was evaluated for specificity, accuracy, linearity and stability of the solution. Drugs also suffer from acid, alkaline and oxidation

hydrolysis conditions stressful Drugs $\left(30 \% \mathrm{v} / \mathrm{v} \mathrm{H}_{2} \mathrm{O}_{2}\right)[3]$.

\section{Method Development}

TRAIL-1

Preparation of buffer

Take 295mg potassium dihydrogen phosphate of $0.02 \mathrm{M}$ was melted in $100 \mathrm{ml}$ of water and regulate the $\mathrm{pH}-3$ using diluted 0 phosphoric acid [4]. 


\section{Preparation of mobile phase}

Clean and degassed combination of acetonitrile: bumper in the ratio of 50:50 and filter through 0.45 micron membrane filter [4].

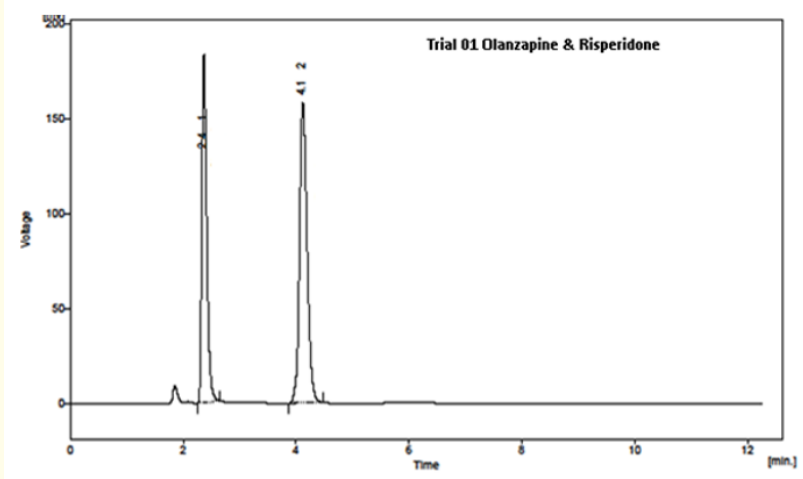

Figure 1: Olanzapine and Risperidone (Acetonitrile: Potassium Di Hydrogen Phosphate Buffer (50:50 V/V)).

TRAIL-2

\section{Preparation of buffer}

Take $295 \mathrm{mg}$ of $0.02 \mathrm{M}$ potassium dihydrogen orthophosphate was melted in $100 \mathrm{ml}$ of water and adjust the $\mathrm{pH}-4.5$ using diluted 0-phosphoric acid [5].

\section{Preparation of mobile phase}

Filtered and vented mixture of acetonitrile: buffer in the ratio of 40:60 and filter through 0.45 micron membrane filter [5].

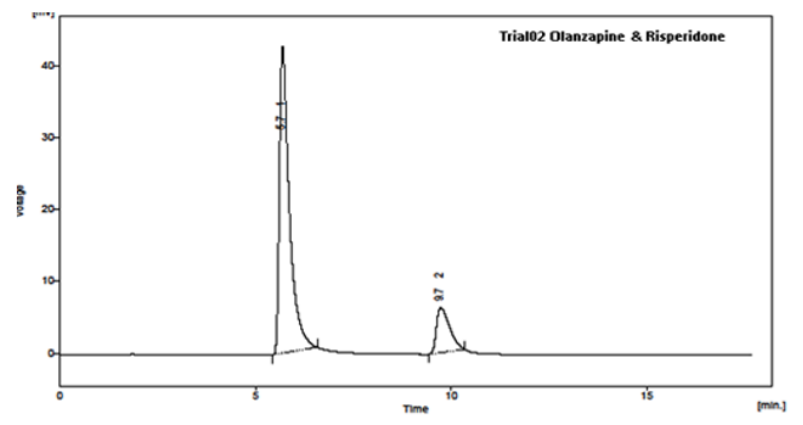

Figure 2: Olanzapine and Risperidone (Acetonitrile: Potassium Di Hydrogen Phosphate Buffer (40:60 V/V)).

\begin{tabular}{|l|c|c|c|c|c|}
\hline Trial & Mobile & Result & $\begin{array}{c}\text { Wave- } \\
\text { length }\end{array}$ & pH & Flow \\
\hline 1 & $\begin{array}{c}\mathrm{ACN}: \mathrm{KH}_{2} \mathrm{PO}_{4} \\
(50: 50)\end{array}$ & Good result & 235 & 5.5 & $1 \mathrm{ml} / 1 \mathrm{~min}$ \\
\hline 2 & $\begin{array}{c}\mathrm{ACN}: \mathrm{KH}_{2} \mathrm{PO}_{4} \\
(40: 60)\end{array}$ & $\begin{array}{c}\text { Less } \\
\text { retention } \\
\text { time }\end{array}$ & 235 & 4.5 & $1 \mathrm{ml} / 1 \mathrm{~min}$ \\
\hline
\end{tabular}

Table 1

Initialization of the instrument

The column has originally been put on the instrument and the instruments have been switched on, cleaned with acetonitrile for 30 minutes: water $(20: 80)$. The system was then designed to operate for column saturation in the mobile phase for 30 minutes [6].

\section{Standard preparation of olanzapine and risperidone}

Standard-A: Precise weighed amounts of $10 \mathrm{mg}$ Olanzapine into a $100 \mathrm{ml}$ volumetric bottle, and diluent to the capacity. A volumetric flask of $5 \mathrm{ml}$ was pipelined into the same diluent in the volume and then produced [6].

Standard-B: Accurately weighed amount of $5 \mathrm{mg}$ of risk peri done in a $100 \mathrm{ml}$ volumetric flask and thinned to the capacity. This $5 \mathrm{ml}$ was then piped into a flask of $50 \mathrm{~mL}$ and composed with same diluents up to the capacity [6].

\begin{tabular}{|l|c|}
\hline \multicolumn{1}{|c|}{ Mode of operation } & Isocratic \\
\hline Parameters & Description \\
\hline Diluents & Water \\
\hline Column & $\begin{array}{c}\text { C18, } 250 \times 4.6 \mathrm{~mm}, 5 \mu \mathrm{SS} \\
\text { column }\end{array}$ \\
\hline Mobile phase & $\begin{array}{c}\text { Acetonitrile: Potassium } \\
\text { Di Hydrogen Phosphate } \\
(50: 50)\end{array}$ \\
\hline Flow rate & $1.0 \mathrm{ml} / \mathrm{min}$ \\
\hline $\begin{array}{l}\text { Detection of Olanzapine and } \\
\text { Risperidone }\end{array}$ & $235 \mathrm{~nm}$ \\
\hline Temperature & $25^{\circ} \mathrm{C}$ \\
\hline Injection Volume & $20 \mu \mathrm{l}$ \\
\hline Run time & $20 \mathrm{~min}$ \\
\hline Detector & UV detector \\
\hline
\end{tabular}

Table 2: Chromatographic conditions. 


\begin{tabular}{|l|c|}
\hline \multicolumn{1}{|c|}{ Parameters } & \multicolumn{1}{c|}{ Conditions } \\
\hline Column (Stationary Phase) & $\begin{array}{r}\text { WATERS C18 Symmetry (4.6 } \\
\text { x 250mm, } 5 \mu \mathrm{m})\end{array}$ \\
\hline Mobile Phase & $\begin{array}{r}\text { Acetonitrile: Potassium } \\
\text { Di Hydrogen Phosphate } \\
(50: 50)\end{array}$ \\
\hline Flow rate (ml/min) & $1 \mathrm{ml} / \mathrm{mm}$. \\
\hline Run time (min) & 20 \\
\hline Column temperature $\left({ }^{\circ} \mathrm{C}\right)$ & $25^{\circ} \mathrm{C}$ \\
\hline $\begin{array}{l}\text { Volume of injection loop } \\
(\mu \mathrm{l})\end{array}$ & $20 \mu \mathrm{l}$ \\
\hline Detection wavelength $(\mathrm{nm})$ & 235 \\
\hline Drug RT (min) & $2.2,4.1$ \\
\hline
\end{tabular}

Table 3: Optimized method parameters.

\section{Validation parameters}

The technique has been validated using numerous parameters since the HPLC technique was created in order to guarantee that the method's performance characteristic satisfies the criteria for the intended analysis applications [7].

System suitability

\section{Preparation of standard solution}

Accurately weighed in $50 \mathrm{ml}$ volumetric flask 10 milligrams of olanzapine and $5 \mathrm{mg}$ Risperidone to mobile phase volume. Dilute volumetric flask to the mobile phase volume [8].

\section{Specificity}

Specificity is the capacity to evaluate an analyte definitively when components are present that may be predicted to exist. The specificity specifies that the procedure must not be impacted by the attendance of other mechanisms in the concurrent assessment of olanzapine and riskperidone. The specialty would usually be carried out by allowing the sample under stressful circumstances [9].

\section{Heating}

$1 \mathrm{~mL}$ from the stock answer in a $10 \mathrm{~mL}$ bottle up to mobile phase volume should be collected for the specificity investigation. For a time period of 30 minutes the answer should be heated at $40{ }^{\circ} \mathrm{C}$. Note that any breakdown takes place or not [10].
Treating with acids

In the $10 \mathrm{~mL}$ flask take $1 \mathrm{~mL}$ of the packaging solution. Add $1 \mathrm{~mL}$ hydrochloric acid to this bottle. To it. Notice of any changes in the preservation of the summit [11].

\section{Treating with base}

Add $1 \mathrm{~mL}$ of $0.1 \mathrm{M}$ of hydroxide sodium from a solution containing stocks into a $10 \mathrm{ml}$ flask. Notice any degradation [12].

\section{Linearity}

Preparation of standard stock solution

10 milligrams of olanzapine and $5 \mathrm{mg}$ of riskperidone diluted to volume with mobile phase in $50 \mathrm{ml}$ volumetric fiber Dilute volumetric flask to the mobile stage volume [13].

Preparation of linearity solution-I: Transfer $1 \mathrm{ml}$ with mobile phase from stock to $10 \mathrm{ml}$ (the solution becomes 2 mcg of olanzapine and 1mcg of Risperidone) [13]

Preparation of linearity solution-II: Transfer $2 \mathrm{ml}$ containing the moving phase from standard solution to $10 \mathrm{ml}$ (the solution becomes $4 \mathrm{mcg}$ of olanzapine and $2 \mathrm{mcg}$ of Risperidone) [13]

Determination: The linearity of the analysis technique is evaluated by the mathematical treatment of analysis findings from samples having analyte levels over the specified range. The area is graphed according to the concentration of the analyte. Curve fits are determined by percentage [13].

Acceptance criteria: The coefficient of correlation and regression for Olanzapine and Risperidone must not be less than 0.99 [13].

\section{System precision}

\section{Preparation of stock solution}

Weigh $10 \mathrm{mg}$ Olanzapine and $5 \mathrm{mg}$ Risperidone in $50 \mathrm{ml}$ Volumetric Flask Dilute To Volume with Moveable Phase [14].

\section{Dilution}

Transfer $5 \mathrm{ml}$ from stock solution to $100 \mathrm{ml}$ with mobile phase (the solution becomes $10 \mathrm{mcg}$ of olanzapine and $5 \mathrm{mcg}$ of Risperidone) [14]

\section{Accuracy}

Preparation of stock solution

Weigh $10 \mathrm{mg}$ olanzapine and $5 \mathrm{mg}$ Risperidone in $50 \mathrm{ml}$ volumetric flask dilute to volume with mobile phase [15]. 


\section{Preparation of spiking standard}

Transfer $5 \mathrm{ml}$ from stock solution to $100 \mathrm{ml}$ with mobile phase.

Preparation of accuracy solution 1: Transfer $4 \mathrm{ml}(8 \mathrm{mcg}$ olanzapine and $4 \mathrm{mcg}$ riskperidone) from stock solution to $100 \mathrm{ml}$ with motive phase and add $1 \mathrm{ml}$ Spiking Standard [15].

Preparation of accuracy solution 2: Transfer to $100 \mathrm{ml}(10 \%$ Olanzapine and 5\% Risperidon) and add $1 \mathrm{ml}$ of Spiking Standard ( $5 \mathrm{ml}$ of stock solution with mobile phase) and add to the package [15].

Preparation of accuracy solution 3: Transfer to $100 \mathrm{ml} \mathrm{(12} \mathrm{mcg}$ olanzapine and $6 \mathrm{mcg}$ risk peridone), moving from stock solution, and add to the standard $1 \mathrm{ml}$ [15].

\section{Method precision}

Stock solution

Weigh $10 \mathrm{mg}$ olanzapine and $5 \mathrm{mg}$ Risperidone in $50 \mathrm{ml}$ Volumetric Flask, Dilute to Volume with Mobile Phase [16].

\section{Dilution}

Transfer $5 \mathrm{ml}$ from stock solution to $100 \mathrm{ml}$ with mobile phase (the solution becomes $10 \mathrm{mcg}$ of olanzapine and $5 \mathrm{mcg}$ of Risperidone) [16].

Assay

Preparation of stock solution

Weigh $10 \mathrm{mg}$ olanzapine and $5 \mathrm{mg}$ Risperidone in $50 \mathrm{ml}$ volumetric flask dilute to volume with mobile phase [15].

\section{Preparation of standard solution}

Transfer $5 \mathrm{ml}$ from stock solution to $100 \mathrm{ml}$ with mobile phase (The solution becomes $10 \mathrm{mcg}$ of olanzapine and $5 \mathrm{mcg}$ of Risperidone) [15].

\section{Ruggedness}

Ruggedness study was approved out by repeating the complete experimentation with different analysts, on dissimilar days in same workroom as per the following preparation [15].

\section{Blank solution}

Purity water was used as diluents.
Stock solution

Weigh $10 \mathrm{mg}$ Olanzapine and $5 \mathrm{mg}$ Risperidone in $50 \mathrm{ml}$ Volumetric Flask Dilute to Volume With Mobile Phase [14].

\section{Dilution}

Transfer to $100 \mathrm{ml}$ of mobile phase $5 \mathrm{ml}$ of stock solution (the solution becomes $10 \mathrm{mcg}$ of olanzapine and $5 \mathrm{mcg}$ of Risperidone) [13].

\section{Determination}

A sufficient number of samples shall be evaluated and a relative default shall be calculated by means of the test method and tool.

\section{Acceptance criteria}

The relative standard deviation should not be less than $2 \%$.

\section{Robustness}

Stock solution

Weigh $10 \mathrm{mg}$ Olanzapine and $5 \mathrm{mg}$ Risperidone in $50 \mathrm{ml}$ volumetric flask dilute to volume with mobile phase [11].

\section{Dilution}

Transfer $5 \mathrm{ml}$ from stock solution to $100 \mathrm{ml}$ with mobile phase (the solution becomes $10 \mathrm{mcg}$ of olanzapine and $5 \mathrm{mcg}$ of Risperidone) [15].

\begin{tabular}{|l|c|c|c|}
\hline S. No & $\begin{array}{c}\text { Chromatographic } \\
\text { condition }\end{array}$ & Low & High \\
\hline 1. & Flow rate & $0.9 \mathrm{ml}$ & $1.1 \mathrm{ml}$ \\
\hline 2. & Wavelength & $235 \mathrm{~nm}$ & $237 \mathrm{~nm}$ \\
\hline
\end{tabular}

Table

\section{Determination}

An analysis of aliquots of homogeneous lot, using different physical parameters that may be different but are yet within the specified parameters of the assay, shall determine the robustness of an analytical approach [13].

\section{Acceptance criteria}

The percentage assay of drugs should be within the limit of 90 $110 \%$. 


\section{Results and Discussion}

TRAIL-1

System suitability results

Olanzapine and Risperidone

- Tailing factor obtained from trail- 1 was 1.700 and 1.412

- $\quad$ Theoretical plates obtained from trail-1 was 3562 and 4798

- $\quad$ Resolution obtained from trail-1 was 8.843

- Retention time obtained from trail-1 was 2.367 and 4.120 [11].

TRAIL-2

System suitability results

Olanzapine and Risperidone

- $\quad$ Tailing factor obtained from trail- 2 was 2.909 and 2.458

- Theoretical plates obtained from trail-2 was 2795 and 3635

- Resolution obtained from trail-2 was 7.513

- Retention time obtained from trail-2 was 5.690 and 9.733 [12].

Trails result

On the evaluation of above system suitability results,

- System suitability parameters of trail-I were within the satisfactory limits.

Hence trail II shows variation in system suitability results and affected the method significantly. Trail-I shows good system suitability results and also within in the limit so the trail - I was adopted [14].

Validation results

System suitability

\begin{tabular}{|l|c|c|}
\hline S No. & Parameter & Olenzapine \\
\hline 1 & RT (min) & 2.2 \\
\hline 2 & Tailing Factor & 1.5 \\
\hline 3 & No. of theoretical & 2557.000 \\
& plates & \\
\hline
\end{tabular}

Table 4: System suitability results for olanzapine.

\begin{tabular}{|l|c|c|}
\hline S No. & Parameter & Risperidone \\
\hline 1 & RT (min) & 4.1 \\
\hline 2 & Tailing Factor & 1.4 \\
\hline 3 & No. of theoretical & 7051.000 \\
\hline
\end{tabular}

Table 5: System suitability results for Risperidone.

Result

On the evaluation of above results it was found that all the system suitability parameters were within the satisfactory limit.

\section{Specificity}

Diluents, standard preparation and assay were prepared as per the method and the solutions were vaccinated into the chromatograph and the chromatograms logged. The retention time given in the following table [7].

\begin{tabular}{|l|c|c|}
\hline S.no & Solution & $\begin{array}{c}\text { Retention } \\
\text { time (min) }\end{array}$ \\
\hline 1. & Olanzapine Standard preparation & 2.23 \\
\hline 2. & Olanzapine assay preparation & 2.01 \\
\hline 3. & Risperidone standard preparation & 5.05 \\
\hline 4. & Risperidone assay preparation & 5.02 \\
\hline
\end{tabular}

Table 6: Specificity results for Olanzapine and Risperidone.

\begin{tabular}{|l|c|c|}
\hline S.no & Stress conditions & Observed result \\
\hline 1. & Heated on water bath & No degradation occurred \\
\hline 2. & Treated with acids & $\begin{array}{c}\text { No change in retention of } \\
\text { the } \\
\text { peak }\end{array}$ \\
\hline 3. & Treated with base & No degradants formed \\
\hline
\end{tabular}

Table 7: Specificity results for Olanzapine and Risperidone under stress conditions. 
Result

- No peaks should be detected at the retention time of Olanzapine and Risperidone in the chromatograms of diluents preparation

- From the stress conditions performed, various degradation products were formed and there was no change in the detection of the analyte in the presence of other components.

Accuracy

\begin{tabular}{|c|c|c|c|c|c|}
\hline \begin{tabular}{|c|}
$\%$ Concen- \\
tration \\
(at specifica- \\
tion Level)
\end{tabular} & Area & $\begin{array}{c}\text { Amount } \\
\text { Added } \\
\text { (mcg) }\end{array}$ & $\begin{array}{c}\text { Amount } \\
\text { Found } \\
\text { (mcg) }\end{array}$ & $\begin{array}{l}\text { \% Re- } \\
\text { covery }\end{array}$ & $\begin{array}{c}\text { Mean } \\
\text { Recovery }\end{array}$ \\
\hline $80 \%$ & 154.4297 & 9 & 8.93 & $99.26 \%$ & \multirow{3}{*}{$99.44 \%$} \\
\hline $100 \%$ & 189.5143 & 11 & 10.96 & $99.66 \%$ & \\
\hline $120 \%$ & 223.4167 & 13 & 12.92 & $99.41 \%$ & \\
\hline
\end{tabular}

Table 8: The accuracy results for olanzapine.

\section{Acceptance criteria}

The \% Recovery for each level should be between 98.0 to $102.0 \%$.

\begin{tabular}{|c|c|c|c|c|c|}
\hline $\begin{array}{l}\% \text { Concen- } \\
\text { tration } \\
\text { (at speci- } \\
\text { fication } \\
\text { Level) }\end{array}$ & Area & $\begin{array}{c}\text { Amount } \\
\text { Added } \\
\text { (mcg) }\end{array}$ & $\begin{array}{l}\text { Amount } \\
\text { Found } \\
\text { (mcg) }\end{array}$ & \% Recovery & $\begin{array}{c}\text { Mean } \\
\text { Recovery }\end{array}$ \\
\hline $80 \%$ & 92.97033 & 4 & 3.88 & $99.34 \%$ & \\
\hline $100 \%$ & 113.7897 & 6 & 5.89 & $99.48 \%$ & \\
\hline $120 \%$ & 135.1153 & 8 & 7.99 & $99.95 \%$ & $99.59 \%$ \\
\hline
\end{tabular}

Table 9: The accuracy results for risperidone.

\section{Acceptance criteria}

The percentage recovery should vary from 98.0 to 102.0 for each level.

\section{Discussion}

On the evaluation above results \% recovery of the drug shows 99.5\% hence the method is found to be accurate.

Method precision

\begin{tabular}{|l|c|c|}
\hline \multicolumn{1}{|c|}{ S No. } & Rt & Area \\
\hline 1 & 2.21 & 171.772 \\
\hline 2 & 2.19 & 173.657 \\
\hline 3 & 2.217 & 173.768 \\
\hline 4 & 2.2 & 174.41 \\
\hline 5 & 2.207 & 172.398 \\
\hline Avg & 2.2048 & 173.201 \\
\hline St. dev & 0.010281 & 1.081429 \\
\hline \%RSD & 0.47 & 0.62 \\
\hline
\end{tabular}

Table 10: Method precision results (Olanzapine).

\begin{tabular}{|l|c|c|}
\hline \multicolumn{1}{|c|}{ S No. } & Rt & Area \\
\hline 1 & 5.077 & 104.183 \\
\hline 2 & 5.053 & 104.585 \\
\hline 3 & 5.097 & 105.061 \\
\hline 4 & 5.053 & 104.819 \\
\hline 5 & 5.073 & 104.958 \\
\hline Avg & 5.0706 & 104.7212 \\
\hline St dev & 0.018461 & 0.349754 \\
\hline \%RSD & 0.36 & 0.33 \\
\hline
\end{tabular}

Table 11: Method precision results (Risperidone).

\section{Acceptance criteria}

The RSD percentage should not exceed $2 \%$ for the five standard injection results.

Discussion

On the evaluation above results \% RSD values are within the limit hence the method is precise.

Ruggedness

\begin{tabular}{|l|c|c|}
\hline Injections & \multicolumn{2}{|c|}{ Area } \\
\hline & Analyst-1 & Analyst-2 \\
\hline 1 & 174.236 & 175.224 \\
\hline 2 & 172.238 & 172.344 \\
\hline 3 & 173.244 & 174.432 \\
\hline 4 & 173.322 & 171.238 \\
\hline 5 & 174.414 & 173.224 \\
\hline 6 & 172.314 & 173.382 \\
\hline Avg & 173.2947 & 173.3073 \\
\hline Std dev & 0.918758 & 1.425564 \\
\hline$\%$ RSD & 0.52 & 0.82 \\
\hline
\end{tabular}

Table 12: Intermediate precision (ruggedness) for Olanzapine. 


\begin{tabular}{|l|c|c|}
\hline Injections & \multicolumn{2}{|c|}{ Area } \\
\hline & Analyst-1 & Analyst-2 \\
\hline 1 & 105.715 & 106.734 \\
\hline 2 & 104.722 & 105.735 \\
\hline 3 & 105.744 & 106.765 \\
\hline 4 & 103.755 & 106.788 \\
\hline 5 & 105.711 & 105.734 \\
\hline 6 & 104.760 & 105.797 \\
\hline Avg & 105.0678 & 106.089 \\
\hline Std dev & 0.80344 & 1.336743 \\
\hline$\%$ RSD & 0.76 & 0.84 \\
\hline
\end{tabular}

Table 13: Intermediate precision (ruggedness) for Risperidone.

\section{Discussion}

The $\%$ RSD is less than $2 \%$ for the results of two analyst indicating the ruggedness of the method.

\section{Robustness}

By making small variations to the process parameters like flow rate changes by \pm 10 percent of actual flow rate, the robustness of the method is determined.

\begin{tabular}{|c|c|c|c|}
\hline \multirow{2}{*}{$\begin{array}{c}\text { S } \\
\text { No. }\end{array}$} & \multirow{2}{*}{$\begin{array}{c}\text { Flow Rate } \\
\text { (ml/min) }\end{array}$} & \multicolumn{2}{|c|}{\begin{tabular}{c} 
System Suitability Results \\
\cline { 3 - 4 }
\end{tabular}} \\
\cline { 3 - 4 } Count & USP Tailing \\
\hline 1 & 0.9 & 3191 & 1.544 \\
\hline 2 & 1.1 & 7037 & 1.446 \\
\hline
\end{tabular}

Table 14: Results for Olanzapine.

\begin{tabular}{|c|c|c|c|}
\hline \multirow[b]{2}{*}{ S No. } & \multirow{2}{*}{$\begin{array}{l}\text { Flow Rate } \\
\text { (ml/min) }\end{array}$} & \multicolumn{2}{|c|}{ System Suitability Results } \\
\hline & & $\begin{array}{c}\text { USP Plate } \\
\text { Count }\end{array}$ & USP Tailing \\
\hline 1 & 0.9 & 7512 & 1.431 \\
\hline 3 & 1.1 & 2772 & 1.518 \\
\hline
\end{tabular}

Table 15: Results for Risperidone.

\section{Summary and Conclusion}

The RP-HPLC technique for the simultaneous assessment in combination dose form of olanzapine and risperidone has been

tested. As the literature review showed, few techniques are available at a time, but a simple, cost-effective and correct technique for estimating the aforesaid combination in combined dose form is required.

HPLC Water The mobile phases of buffer dipotassium hydrogen phosphate: acetonitrile (50:30), which was pumped at a flow rate of $1 \mathrm{~mL} / \mathrm{min}$ and measured by a UV detector, have been injected using sickrooms 21cfr software, UV detector and C18 symmetry column $(250 \mathrm{~mm}$ X $4.6 \mathrm{~mm}, 5 \mu)$. At 2.2 and 4.1 respectively, the maxima of Olanzapine and Risperidone were well separated.

Different deteriorating products have been shown to be selective and there are no changes to analyte detection in the presence of other components.

The system adequacy investigations indicated that all system adequacy parameters were subject to the criterion of approval.

The findings shown in precise terms were that for Olanzapine 99.4\% for Risperidone were the percentage recovery values of pure medication from the pre-analyzed formulations, indicating that the procedure was accurate.

Robustness findings have been shown that with the change in parameters such as flow rate and wave length, there is minimal change in findings, which indicate the robustness of the approach.

The chromatographic technique devised to determine the dose of Olanzapine And Risperidone was simple, fast, accurate, specific, robust, and cost effective. The mobile phase is easy to prepare and cost-effective, dependable and time saving.

Given that the system suitability trials and their validation tests have also been successful, it is determined to be most beneficial for analytical purposes that the simple and short recommended approach is.

\section{Conflict of Interest}

The authors have no conflicts of interest.

\section{Bibliography}

1. Meltzer HERBERT Y and J Frank Nash. "Effects of antipsychotic drugs on serotonin receptors". Pharmacological Reviews 43.4 (1991): 587-604. 
2. Meltzer Herbert Y. "The role of serotonin in antipsychotic drug action". Neuropsychopharmacology 21.1 (1999): 106-115.

3. Lerner Vladimir., et al. "Combination of "atypical” antipsychotic medication in the management of treatment-resistant schizophrenia and schizoaffective disorder". Progress in Neuro-Psychopharmacology and Biological Psychiatry 28.1 (2004): 89-98.

4. Venkata Kiran B., et al. "Validation of quetiapine fumarate in pharmaceutical dosage by reverse-phase HPLC with internal standard method". Journal of Chemistry 2013 (2013).

5. Frahnert Christine., et al. "Analysis of eighteen antidepressants, four atypical antipsychotics and active metabolites in serum by liquid chromatography: a simple tool for therapeutic drug monitoring". Journal of Chromatography B 794.1 (2003): 35-47.

6. Gurunadha Reddy G. "Simultaneous Estimation of Olanzapine and Fluoxetine Hydrochloride in Tablet Dosage form by Reverse Phase High Performance Liquid Chromatography". Diss. KK College of Pharmacy, Chennai (2012).

7. Borecka Marta., et al. "A new approach for the estimation of expanded uncertainty of results of an analytical method developed for determining antibiotics in seawater using solid-phase extraction disks and liquid chromatography coupled with tandem mass spectrometry technique". Journal of Chromatography A 1304 (2013): 138-146.

8. Suthar AP., et al. "Determination of Risperidone and forced degradation behavior by HPLC in tablet dosage form". International Journal of PharmTech Research 1.3 (2009): 568-574.

9. Hamilton Robert G. "Assessment of human allergic diseases". Clinical immunology. Content Repository Only! (2019): 12831295.

10. Dahl Darwin B and Peter F Lott. "Gunshot residue determination by means of gunpowder stabilizers using high-performance liquid chromatography with electrochemical detection and analysis of metallic residues by graphite furnace atomic absorption spectrophotometry". Microchemical Journal 35.3 (1987): 347-359.

11. Morales-de La Peña M., et al. "Changes on phenolic and carotenoid composition of high intensity pulsed electric field and thermally treated fruit juice-soymilk beverages during refrigerated storage". Food Chemistry 129.3 (2011): 982-990.

12. Jaafarzadeh Nematollah., et al. "Efficient degradation of 2, 4-dichlorophenoxyacetic acid by peroxymonosulfate/magnetic copper ferrite nanoparticles/ozone: a novel combination of advanced oxidation processes". Chemical Engineering Journal 320 (2017): 436-447.

13. Morales-de La Peña M., et al. "Changes on phenolic and carotenoid composition of high intensity pulsed electric field and thermally treated fruit juice-soymilk beverages during refrigerated storage". Food Chemistry 129.3 (2011): 982-990.

14. Ray Bryan Hubert. "SERS analysis of biological analytes using an azo tether". University of Wyoming, (2005).

15. Ratzoni Gidi., et al. "Weight gain associated with olanzapine and risperidone in adolescent patients: a comparative prospective study". Journal of the American Academy of Child and Adolescent Psychiatry 41.3 (2002): 337-343.

\section{Volume 5 Issue 8 August 2021 (C) All rights are reserved by Bharat Lal and Manoj Gadewar.}

